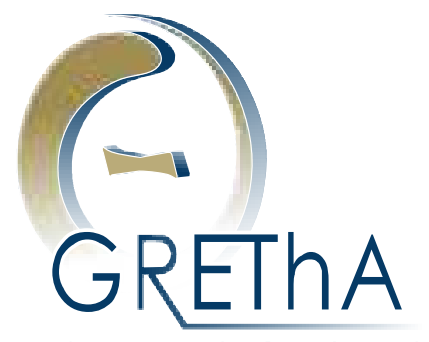

Groupe de Recherche en

Économie Théorique et Appliquée

\title{
Moderate Prosperity, an adaptation of the Middle Class concept to a Malagasy rural area: the case of Itasy
}

\author{
Tsiry ANDRIANAMPIARIVO \\ GREThA, CNRS, UMR 5113 \\ Université de Bordeaux
}

Cahiers du GREThA

$n^{\circ}$ 2014-20

December

\section{GRETHA UMR CNRS 5113}

Université de Bordeaux

Avenue Léon Duguit - 33608 PESSAC - FRANCE

Tel : +33 (0)5.56.84.25.75 - Fax : +33 (0)5.56.84.86.47 - www.gretha.fr 
Petite Prospérité, une adaptation du concept de Classe Moyenne en milieu rural malgache: le cas d'Itasy

Résumé

Nous discutons et testons la pertinence de l'adaptation du très controversé concept sociologique de " Classe Moyenne " en milieu rural africain. Nous proposons le concept de Petite Prospérité et I'appliquons en milieu rural malgache, plus précisément dans la région d'Itasy. L'objectif de cet article est de mettre l'accent sur les dynamiques rurales et de comprendre les changements socioéconomiques en cours à Madagascar qui est un pays à base agricole. En adoptant une étude de cas, nous mobilisons des données détaillées sur 510 ménages provenant de l'Observatoire d'Itasy en 2008. D'abord, nous définissons les ménages de la Petite Prospérité comme étant ceux qui appartiennent aux trois derniers quintiles de la distribution du revenu. Ensuite, nous classons les ménages identifiés en considérant simultanément le niveau d'éducation de leur chef, la structure de leur revenu et leur propriété foncière. Nous décrivons cinq groupes différents de Petite Prospérité qui illustrent la diversité agro-économique de l'Itasy : (i) le large groupe vulnérable des ménages ayant un chef peu éduqué, des activités non-agricoles et d'élevage et détenant un titre foncier formel, (ii) le groupe traditionnel des riziculteurs à faible niveau d'éducation et possédant des grandes propriétés, (iii) le groupe émergent des polyculteurs qualifiés détenant un titre foncier traditionnel, (iv) le groupe de la petite prospérité supérieur des salariés non-agricoles éduqués et (v) le groupe de la petite prospérité inférieur des petits exploitants relativement qualifiés, ayant des activités non-agricoles mais ne possédant aucun titre de propriété foncier.

Mots-clés : stratification sociale, classe moyenne, petite prospérité, milieu rural malgache, ménages agricoles, méthodes de classification.

Moderate Prosperity, an adaptation of the Middle Class concept to a Malagasy rural area: the case of Itasy

\begin{abstract}
We discuss and test the relevance of the adaptation of the controversial sociological concept of "Middle Class" to African rural areas. We propose the concept of Moderate Prosperity and apply it to the Malagasy rural area, particularly in the Itasy region. This paper aims to emphasize the rural dynamics and to understand the ongoing socioeconomic changes in Madagascar as an agriculturebased country. Adopting a case study, we use detailed data on 510 households from the 2008 Itasy Observatory. We first define Moderate Prosperity households as being those in the top three quintiles of the income distribution. Then we classify the households thus identified using, simultaneously, the household head's education level, the household's income structure and its rice land tenure. We describe five different Moderate Prosperity clusters that reflect the agro-economic diversity of Itasy: (i) the large, vulnerable group of uneducated, non-farming and livestock farming households with formal land title, (ii) the traditional group of uneducated rice farmers with large holdings, (iii) the emerging group of skilled, polyculture farmers with traditional land ownership, (iv) the upper moderate group of educated non-agricultural workers and $(v)$ the lower moderate cluster of skilled smallholders in independent and non-farm activities without any land tenure.
\end{abstract}

Keywords: social stratification, middle class, moderate prosperity, rural Madagascar, farm households, clustering methods.

JEL: C38, 055, P46, Q12, Z13

Reference to this paper: ANDRIANAMPIARIVO Tsiry (2014) Moderate Prosperity, an adaptation of the Middle Class concept to a Malagasy rural area: the case of Itasy, Cahiers du GREThA, $\mathrm{n}^{\circ} 2014-20$.

http://ideas.repec.org/p/grt/wpegrt/2014-20.html. 


\section{Introduction}

During the last decade, development economics literature and policy debates have shown a keen interest in the growing "Middle Class" in developing economies. The borrowing of this controversial concept of traditional class analysis from the sociological literature provides a superficial analogy with the case of Western Middle Classes of the postwar period. There is a strong hope that the emerging middle category of people in developing countries will be a significant engine of sustainable growth and a driver of socioeconomic development and political stability. In theoretical models, a large, wealthy Middle Class has particular behaviors, values and expectations that make it a development lever through many channels. First, the term "Middle Class" often refers to skilled people with investment and saving potentials (Doekpe and Zilibotti, 2008; Acemuglu and Zilibotti, 1997). Second, the standard of living and lifestyle of the Middle Classes are stimulators of consumption that may sustain internal growth through the development of domestic markets (Banerjee and Duflo, 2008; Senauer and Goetz, 2003). Third, a large Middle Class is likely to develop a more inclusive and cohesive society and favor social policies and strengthening of institutions and thus to support democracy (Loayza et al., 2012; Easterly, 2001). These hypothetical virtues are expected from a large and homogenous Middle Class or Global Middle Class (WB, 2007) which is a phenomenon more specific to middle-income countries (MICs). ${ }^{1}$ In fact, in the least developed countries (LDCs), particularly in Sub-Saharan Africa (SSA), the Middle Class is still missing or is still poor in international terms (Ravallion, 2009; Birdsall, 2007). The concept thus seems inadequate to the African context especially when there is a real vagueness surrounding its definition and its impacts, even for MICs (Darbon, 2012).

Given the above, why is it still so interesting to study the African Middle Class? A reappropriation of the concept in the development economics literature has significant interest both for MICs and LDCs. As a complementary approach to the study of poverty, it marks a broadening of emphasis in the target population by focusing this time on people who are out of poverty and might need particular policies (Birdsall, 2010). It also provides a framework which helps us to appreciate all the ongoing social dynamics and economic changes in developing countries, a framework that is essential for policy makers and developers, particularly in relation to the allocation and effectiveness of aid (Darbon and Toulabor, 2011). It is thus important to adapt the concept of "Middle Class" to the particular characteristics of MICs and LDCs because we cannot find a unique model of 'Middle Class' adapted to any society at any time.

The purpose of this article is to suggest an adaptation and reinterpretation of the concept of "Middle Class" to the context of sub-Saharan countries and we suppose that a particular focus on rural areas is more relevant. The structure of the economic system and the development stage of African LDCs differ from those of MICs. Given their process of structural transformation, they are still agriculture-based countries (WBR, 2008). The

\footnotetext{
${ }^{1}$ This vision of Global Middle Class (GMC) is inspired by the ephemeral concept of Western post-industrial societies always tending towards a wider Middle Class (Bidou-Zacharisien, 2004).
} 
approach predominantly adopted by the majority of recent empirical studies of the Middle Class is thus inadequate for them, since it frequently uses a monetary criterion (income or consumption) and is heavily influenced by a Western vision of the concept with an automatic urban bias (Chun et al., 2011; Easterly, 2001).

In order to study the African Middle Class, Darbon and Toulabor (2011) propose the Moderate Prosperity approach. This category refers to all people who try, within their limited capacity, to escape from extreme poverty in spite of their vulnerability and who are able to adopt micro-investment and micro-accumulation behaviors (Darbon, 2012). Setting aside the idea of studying gentrification, the rural Moderate Prosperity approach thus provides an opportunity to shed light on the discrete dynamics of a 'lower middle category' of people that may best describe the local realities and ongoing changes operating in SSA. This framework may give a better understanding of the African rural and agricultural potential put forward by many studies (Diao et al., 2006; Bezemer and Headay, 2008).

We test the relevance of this approach through the case of the Malagasy region of Itasy. In Madagascar, as in most SSA agriculture-based countries, the majority of the population is rural (69\% in 2008), questions of food security and poverty remain challenging and agriculture and the rural sector still play an important role in the economy (25\% of GDP in 2008). ${ }^{2}$ The Itasy region, which is close to Antananarivo, can provide an interesting illustration of an aspect of Malagasy rural areas with the importance of rice production and the diversification of households' sources of income. Furthermore, the region has long been the object of various rural development projects.

This paper attempts to identify representative "Moderate Prosperity" households in the Itasy rural area in order to analyze their socioeconomic characteristics and their specific behavior patterns. In the same way as Bonnefond et al. (2015), we identify Moderate Prosperity households in the Itasy area by combining an income-based method and a multidimensional and sociological approach (education, income diversification and land tenure). We use household-level data from the $\mathrm{ROR}^{3}$ (rural observatory). This article is organized as follows. First, the conceptual and methodological adaptation of the "Middle Class" concept to African rural areas is addressed by questioning its sociological basis in the development economics literature. Second, we present the Malagasy region of Itasy and describe the data; and finally we present and discuss the main results.

\section{From a Middle Class to a Moderate Prosperity approach: a challenging adaptation of a sociological concept}

\footnotetext{
${ }^{2}$ World Bank: http://www.worldbank.org/

${ }^{3}$ ROR (Réseau des Observatoires Ruraux - Network of Rural Economic Observatories) is a network of rural observatories attached to the Prime Minister of the Malagasy government.
} 
The concept of "Middle Class" refers to the analysis of class structure and stratification. It is a methodological tool that has often been adapted to the study of Western societies (Stavenhagen, 1969). This approach has not been practically applied to societies in the developing world, even less so in rural areas. This is why it is important to adapt and conceptualize what Middle Class might mean in the African context and particularly in rural areas and how to identify it.

\subsection{The Middle Class as a middle income category: a limited stratificationist approach}

There is a significant difference between a class analysis and a social stratification that we will not rigorously take into account in this work, as in most Middle Class studies in the development economics literature. However, beyond an income-based definition, we try to give meaning to our socioeconomic interpretation of the Middle Class concept in a particular rural area of an African LDC.

In class theory, particularly in the Marxist approach, classes are historical and analytical categories in a specific socioeconomic structure. Classes exist only in relation to others and they are defined according to the relationships opposing one to another, due to the differential positions that they occupy in the social structure (Stavenhagen, 1969). In the Western sociological tradition, using Marxist and Weberian approaches, small entrepreneurs (e.g. farmers, shopkeepers, small business owners, etc.) represent the old Middle Class. In an industrial and post-industrial society, the new Middle Class refers to salaried managers, professionals and technicians (Bosc, 2008). The Middle Class, as a class of its own, is then distinguished in the social space by its professional and occupational categories, its standard of living, its specific lifestyle, values and behaviors. The concept has created controversial debates among Western sociologists, thus highlighting the heterogeneity and multipolar nature of the category.

The stratification approach consists of a hierarchical classification of individuals, households or groups (according to the unit of analysis) on a scale of objective criteria (income, consumption, assets, qualifications, prestige etc.), so that some will be at higher levels and others at lower ones. This gradualist method has been the most common approach used by contemporary sociological literature to study society through a stratification system. This method allows the identification of discrete groups on a hierarchical scale rather than classes as in the Marxist approach. This is why in the Anglo-Saxon tradition we find gradual naming as in higher-, middle- or lower-Middle Class. Numerous sociological studies have defined middle classes from a social stratification system using the 'economic approach' of income distribution.

Almost all recent empirical studies in the development economics literature have preferred to define the emerging Middle Class in developing countries through such a stratification approach using in particular a monetary indicator (income, consumption or wage). It consists of a purely statistical identification of supposed relatively homogenous 
Middle Class categories defined as neither poor nor rich. Here, the "Middle Class(es)" refers rather to middle strata or middle group(s) located more or less in the middle of the distribution (Birdsall et al., 2000), but we will use these terms interchangeably. It is obvious that an income-based definition is the most intuitive and the easiest method. However it gives a reductive and limited view of the Middle Class by taking away any sociological sense.

A few studies propose some alternatives to this income-based identification. For instance, Torche and Lopez-Calva (2011), in their study of the Latin American Middle Class, use an index of socioeconomic wellbeing that combines household income with a set of housing quality characteristics (degree of overcrowding, building materials, etc.) and access to services (availability of drinking water, electricity, etc.). Ncube and Shimeles (2012), in their analysis of the African Middle Class, have adopted the same method. Such an index has the advantage of being less sensitive to short-term fluctuations and of considering some symbols of social status in the local context. But objective weightings given to the index components and the problem of thresholds are challenging in a practical sense. Moreover, the advantage of the multidimensionality of the index will be lost in composite information that prevents the characterization of the category.

Another interesting approach is proposed by Bonnefond et al. (2015) who identify the Chinese Middle Class by combining a first step income-based definition with a second step classification based on occupation and education. ${ }^{4}$ This cross-criteria approach allows them to give a sociological context to the Middle Class that has its full meaning in the Chinese context. In addition, the information from the classification allows the Middle Class to be characterized and distinguished within a scale of selected social dimensions. In the same way, given the context of our study (the Itasy region of Madagascar), we will complement an income-based definition with relevant information about the education, source of income and land tenure of the households. The choice of income for a first identification of the category is in line with most studies of Middle Classes in the economics literature. Income is often used to assess the level of well-being of Malagasy rural people or households (Andrianirina et al., 2010; Bockel, 2005; Randrianarison et al., 2007). Then, the second stage of classification aims to refine this distinction by considering some status and social dimensions that distinguish the members of the category in the rural area. In the Itasy context, we will consider the education level of the heads of households to differentiate them in terms of their human capital, which has been the prerogative of sociology since the twentieth century (King and Szelenyi, 2004). In addition, in the absence of occupational status in rural areas, the income structure of the households is used as a proxy. To differentiate the members of the category in the rural production system, we consider the four types of activities that represent the main sources of income in Itasy: rice production; polyculture farming; livestock farming; agricultural employment and other non-farm and independent activities. Finally, access to land is a major factor in inequality of status in rural areas, especially in the Malagasy central

\footnotetext{
${ }^{4}$ They make a classification of the previously-identified Chinese Middle Class based on the education of the head of the household, his/her occupation, employment status and the work unit.
} 
highlands (Ballet and Randrianalijaona, 2010; Droy et al., 2010; Rabearimanana, 1994; Rakoto-Ramanantsoa, 1994; Stavenhagen, 1969).

Once the cross criteria are set, the first income-based definition requires both an identification approach and a scale of analysis. In fact, we have to define who the Middle Class is and how to statistically identify it. This step marks the transition from the Middle Class approach to the Moderate Prosperity approach.

\subsection{The alternative of the Moderate Prosperity approach in African agriculture-based countries}

Almost all empirical studies use a strictly statistical monetary-based (income or consumption) definition of the developing world's Middle Class. Even with this widespread method, there is no consensus about how to isolate this intermediary category from poor and rich and there are controversial debates in recent literature on the appropriate boundaries to identify the developing world's Middle Classes. Although these income-based definitions can be roughly divided into either absolute or relative approaches, there are many methods depending on the considerations that are being emphasized.

First, those using absolute approaches are concerned with international comparisons of the Middle Class and discuss the most appropriate lower boundary. For instance, the World Bank (2007), referring to Milanovic and Yitzhaki (2002), uses the interval of daily per capita income between $\$ 12$ and $\$ 50$ that corresponds respectively to the mean per capita income of Brazil and Italy. Ravallion (2010) meanwhile, considering that these boundaries are more suited to Western Middle Classes, adopts the daily income range between the international poverty line (the median poverty line of 70 developing countries) and that of the United States, i.e. between \$2 and \$13 in PPP 2005. Banerjee and Duflo (2008) propose almost the same income interval between \$2 and \$10 and that of the AfDB (2011) between \$2 and \$20. These lower absolute boundaries better allow the developing world's Middle Class to be defined.

Second, proponents of relative approaches, using either a distribution-based or a median income-based definition, rather consider the specific characteristics of each country. In this way, the most common definitions use the interval between $75 \%$ and $125 \%$ of the median income (Birdsall et al., 2000, Pressman, 2007) or that between 50\% and 150\% of the median income (Castellani and Parent, 2011). Some distribution-based definitions of the Middle Class, such as that of Easterly (2001), consider the middle three quintiles of the income distribution.

Third, a mixed method, put forward by Birdsall (2007, 2010) and Bonnefond et al. (2015), combines the absolute and relative approaches. It consists of fixing an absolute lower threshold ensuring that the identified category is wealthy (non-poor) enough to be Middle Class and a relative and local upper boundary in order to have a country-specific definition. Birdsall (2010) uses an income interval from $\$ 10$ to the $95^{\text {th }}$ percentile of the income 
distribution in each country. Using the poverty-line-based definition can also allow a countryspecific analysis of the Middle Class. A more recent method developed by Lopez-Calva and Ortiz-Juarez (2011) is based on the national poverty line and the vulnerability approach. In their analysis of the Latin American Middle Class, they set a lower threshold of $\$ 10$ from a low probability level of falling into poverty (10 percent) during an observation period and an upper boundary of $\$ 50$.

The use of high-level income criteria in almost all of these empirical studies (especially those using absolute boundaries) aims to ensure that a wealthy enough Middle Class is identified. However, this method emphasizes the fact that this global socioeconomic trend is relevant to Asian and Latin American countries but is absent from African low-income countries (World Bank, 2007; Birdsall, 2007). The marginal part of this category in SubSaharan countries often refers to the rich, elite minority group in the local context. Even with wider and more moderate boundaries, it must be highlighted that the majority of the 'African Middle Class' is concentrated in the lower sub-category of the so-called 'floating class' (people with a daily consumption of between \$2 and \$4), considered as poor in developed countries (AfDB, 2011; Ravallion, 2010). In addition, the automatic urban bias of this approach often refers to a Middle Class composed of medium-sized entrepreneurs and officials, highly educated, urban and modern people etc. (Chun et al., 2011; Easterly, 2001). This excludes the rural areas from such analyses and reduces the rural population to a homogenous peasantry living from agriculture on the economic margin.

Darbon and Toulabor (2011)'s proposal to adopt the Moderate Prosperity approach can provide an alternative means to overcome this lack. The term is based on the Chinese concept of xiaokang which refers to the Chinese ideal society where families reach a security of wellbeing and will fight to extend it in all directions (Xianchun, 2009; Leonard, 2008). Interpreted here at its first stage, it concerns people who have emerged from insecurity and can improve their well-being. These people are still vulnerable but they are able to adopt strategies in order to cope with their socioeconomic environment. Following the Bottom of the Pyramid approach (Prahalad, 2010), it focuses on the potential of people who are on the margin of the 'lower Middle Class' that are ignored by general approaches such as those of a Global Middle Class (Darbon, 2012). In African agriculture-based countries, the adaptation of such an approach to rural areas needs a localized process that takes into account the characteristics of the rural economic structures and gives it a sense in the context being considered (Losch et al., 2011).

Adopting a case study in the rural Itasy region, we aim to include in our analysis households that were able to generate relatively significant income and to exclude the most insecure of them, taking into account the local context. Our reading of the Moderate Prosperity approach aims to overcome the question of poverty thresholds by adopting a relative approach in the first, income-based identification. Based on the income distribution, 
we suggest defining Moderate Prosperity households as those that belong to the top three quintiles. ${ }^{5}$

\section{Context and data}

Who would be in the Moderate Prosperity category in the specific context of rural zones in African agriculture-based countries? These rural areas are characterized by the prevalence of different risks, market failures and price instability and by the lack of infrastructure. Households must cope with such a hostile environment without either social protection or insurance. The region of Itasy presents all the drawbacks of poor rural areas but it has some characteristics that make the study of Moderate Prosperity interesting.

\subsection{Moderate Prosperity in Itasy: an illustration of the rural Middle Class}

In Malagasy rural areas, farmers suffer the effects of agricultural markets characterized by a lack of integration and a high degree of segmentation. For instance, strategic sectors such as rice ${ }^{6}$ have been in difficulty since the 1980 s, when structural adjustment programs led to a period of liberalization and rapid opening up to foreign markets (Roubaud, 1996). They must also cope with the high transaction costs due to the limited access to insurance and financial markets, the problem of pressure on land and the lack of basic infrastructure that isolates many areas. In such a context, the analysis of Moderate Prosperity in Malagasy rural zones allows us to identify households who are able to implement evolving strategies in order to secure their livelihoods and their living conditions.

As an illustration, the approach consists of shedding light on possible market-oriented farmers and rural entrepreneurs who take risks by investing in high-return activities or in equipment and agricultural techniques that may boost their productivity (use of inputs, water control and irrigation, etc.) (Wampfler, 2007). In their analysis of Malagasy rice farmers Bockel (2005) and Bockel and Rakotovao (2001) have already identified such typical profiles. Earlier studies also highlighted the dynamism of some farmers in coping with the crisis of the 1980s and the absence of state supervision (Rabearimanana, 1994; Rakoto-Ramanantsoa, 1994).

In Itasy, some features suggest that the Moderate Prosperity approach is appropriate to the context. First, despite the existence of some isolated areas, the region has the advantage of being close to the capital Antananarivo and some small towns. Second, Itasy portrays a significant aspect of Malagasy rural areas given the preponderance of rice production in the agricultural sector. In fact, it is among the rural regions that achieve the highest average rice yield (3.5 tons/ha against 3 tons/ha in Alaotra ${ }^{7}$ in 2007) and it also manages to market a large proportion of rice produced outside the region (almost $50 \%$ of production in 2001). The

\footnotetext{
${ }^{5}$ See more details in section 4 .

${ }^{6}$ The rice sector contributes $12 \%$ of national GDP and $43 \%$ of agricultural GDP (FAO/UPDR, 2000). It is also the main cereal consumed by Malagasy households.

${ }^{7}$ Alaotra is also known as the rice granary of Madagascar.
} 
region also benefits from good agro-climatic conditions for crop diversity thanks to the volcanic zones. The practice of growing off-season crops (cassava, beans, maize, potatoes etc.) provides households with important food resources during seasons of scarcity and they may also be used as cash crops. Income diversification is also a particular characteristic of the region with off-farm activities including small business, carpentry, basketry, traditional brickmaking, spinning and weaving silk, small-scale manufacture of agricultural equipment, etc. Despite the small scale of such activities that use only limited technologies, they are still important additional sources of income for households. Non-agricultural employment is rare and refers to the few village schoolteachers and some local administrative employees. The presence of agriculture-based industries, such as OFMATA (a tobacco manufacturing company) and LECOFRUIT (a vegetable canning company that collects green beans from the Itasy area) may also give some opportunity for households despite their monopolistic nature. Third, the region is a prime area for development projects in various fields with the participation of the Malagasy Government, many international partners (IFAD, FAO) and some NGOs. For instance, there are projects oriented towards financing infrastructures (FID, PSDR) and included in government rural development policies for the zone (BVPI). Many actors also operate in microfinance (CECAM), in farm advice and in support of non-farm activities and rural entrepreneurs (SAHA, PROSPERER) ${ }^{8}$. Other associations (of a more religious nature) are very active in promoting health and education in the region.

\subsection{Data}

We use data from the ROR covering 510 households from 2005 to 2008 in the Itasy Observatory. The latter is composed of four zones (Ambohidanerana, Anosibe Ifanja, Antanetibe and Merinavaratra) that are roughly representative of the diversity of the social and production systems in the region.

The ROR is a statistical information system on Malagasy rural households initiated by the MADIO project (Madagascar DIAL INSTAT ORSTOM) in 1995. The network currently has fifteen observatories strategically located in the Malagasy rural areas and it has nearly twenty years of experience in household surveys. Surveys conducted annually in each observatory use the household as the statistical unit (around 500 households surveyed per observatory). The questionnaire consists of various detailed modules that allow households' strategies, living conditions and income diversity to be assessed. In addition, the surveys are based on a purposive sampling approach to illustrate the diversity of the Malagasy agro-

\footnotetext{
${ }^{8}$ FID (Fonds d'Investissement pour le Développement - Development Investment Fund) is a collaborative project between the World Bank and the Malagasy Government. PSDR (Rural Development Support Program).

BVPI (Watersheds and Irrigated Zones) is a project of the Malagasy Government that aims to make Itasy a showcase of rice production.

CECAM (Crédits Agricoles Mutuelles - mutualized banks).

SAHA is a local NGO that collaborates with Switzerland.

PROSPERER (Support Program for Rural Micro-Enterprise Centers and Regional Economies of Madagascar) is an initiative of the IFAD, the FAO and the Malagasy Government.
} 
climatic zones and the contrasted living conditions of rural households (Gondard-Delcroix, 2006; Droy and Dubois, 2001).

Our analysis is based on the 2008 survey which is a turning point that marks the end of a period of relative growth with the beginning of the political crisis of 2009. As mentioned above, we have adopted the method used by Bonnefond et al. (2015) that consists of making a two-step identification of Moderate Prosperity in Itasy. The first phase uses an income-based identification in order to isolate the category under consideration and distinguish it from the "precarious" category. The second stage aims to fine-tune the definition of the Moderate Prosperity group using a multidimensional characterization. The three variables for classification are the education level of the household head (illiterate, literate, primary school completed and secondary school completed and more), the form of land tenure (no title, traditional authorization, locally-issued papers, and formal title) and household income structure (rice farmers, agricultural workers, mixed farmers, livestock farmers and selfemployed individuals and non-agricultural workers). The last variable was computed by using a k-means clustering ${ }^{9}$ to classify the households by the proportion of each of these five activities in their total annual income. The classification generated four profiles of income structure that are illustrated in Figure 1.

\section{Figure 1. Income structure profiles}

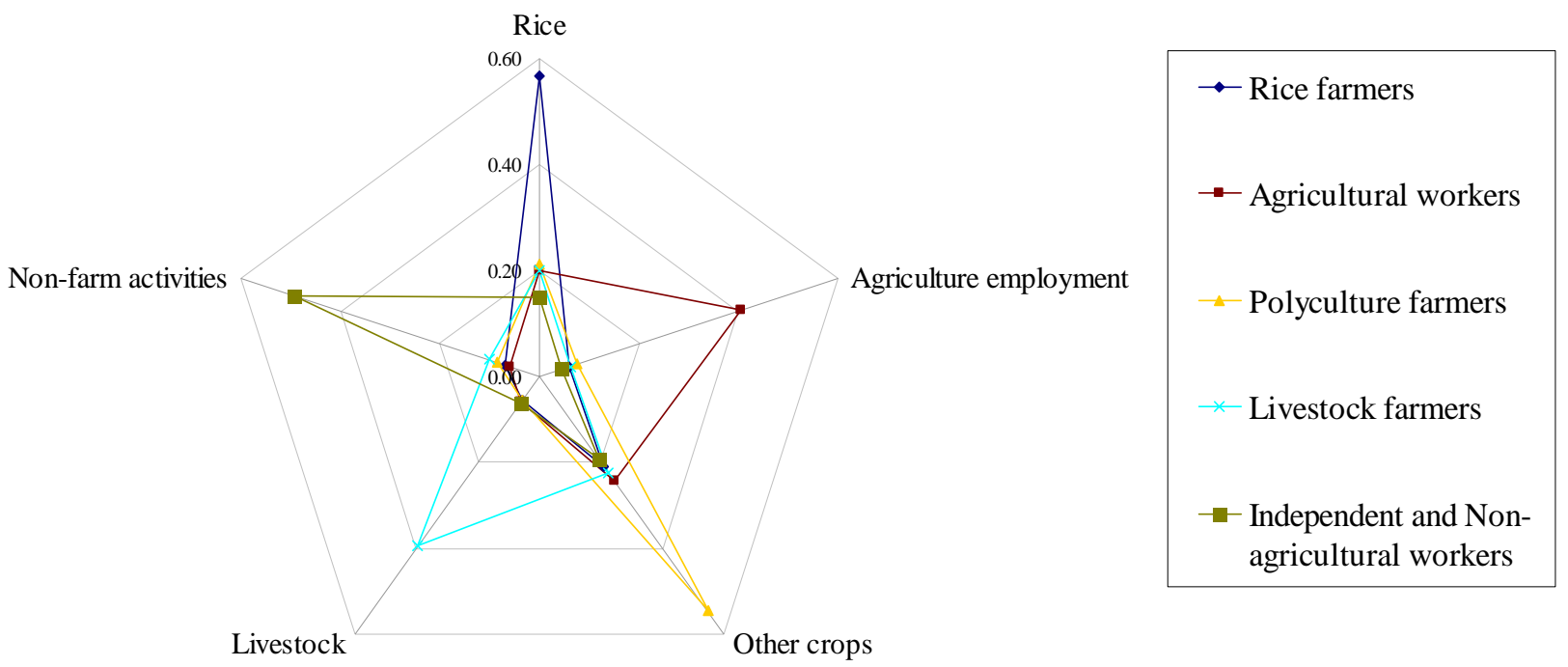

\footnotetext{
${ }^{9}$ The method is developed later.
} 


\section{Empirical analysis and results}

\subsection{First-step identification of the Itasy Moderate Prosperity category and its specific characteristics}

The indicator used in this step is the annual per capita income of the household. We report the total annual gross household income divided by the number of its members. As we have stated, rural households typically have various sources of income from their members' activities and a large degree of self-sufficiency based on their own production. The gross household income was thus computed by combining incomes from non-farm activities, agricultural wages and remittances with the value of the production consumed by the household and sales of all farm produce in 2008.

Households that belong to the top three income quintiles are identified as members of our Moderate Prosperity group and represent $60 \%$ of the sample (after the removal of two outliers). Using the international poverty line of $2 \$$ PPP as in most studies (Banerjee and Duflo, 2008; Ravallion, 2010; AfDB, 2011) allows us to identify just a few households (57 i.e. $11 \%$ of the sample) of which none reached $10 \$ .^{10}$ Furthermore, taking people in the middle of the income distribution (in the three middle quintiles or between $75 \%$ and $125 \%$ of the median income) may include cases of extreme hardship and exclude others with capacities that are of interest for our analysis. In any case, the Moderate Prosperity class that we define differs significantly from the insecure group in terms of household characteristics, livelihoods and strategies, asset ownership, socioeconomic behavior and even in their own evaluation of their living conditions.

In a comparison of the two groups, Table 1 shows that the Itasy Moderate Prosperity category is distinguished by the significant proportion of households whose head has a high level of education (12.5\% have finished secondary school compared with only $3 \%$ in the insecure group). The income structure shows that rice farmers (22.3\%) and livestock farmers (22\%) are significantly representative of the households that compose the moderately well-off category. Agricultural workers are more prevalent in the insecure households group (30\%). The proportion of households who benefit from security of land tenure thanks to the possession of formal titles (38.4\%) is likewise significantly important in the middle category.

Table 2 stresses the fact that Moderate Prosperity households are fairly well distributed among the four zones with an under-representation of women. The mean size of insecure households is higher than that of the Moderate Prosperity category. Furthermore, the Moderate Prosperity category has a significantly high on-farm income and a large proportion of sales of farm produce ( $49 \%$ of the on-farm income). They also have a good food security

\footnotetext{
${ }^{10}$ Only 14 households ( $2.8 \%$ of the sample) exceed a daily per capita income of $4 \$$.
} 
level ${ }^{11}$ which means that these households only have a short season of scarcity thanks to their farm produce and livestock.

As far as households' asset ownership is concerned, it is clear that the Moderate Prosperity households are significantly well endowed and more secure than the insecure category. Indeed, it shows the significance of the size of cattle herds of the Moderate Prosperity households ( 3 times greater than that of the insecure households). The mean area of land cultivated for rice in the Moderate Prosperity group is also twice as large as that for the insecure group. Moreover, the Moderate Prosperity category is noteworthy for the high proportion of households that have a large quantity of durable goods ${ }^{12}(40 \%)$. The specific behavior patterns and accumulation potential of the Moderate Prosperity households are emphasized when compared to the insecure households. For instance, it shows that the majority of households (more than two-thirds) in this category have expenses that are more oriented towards the satisfaction of secondary and even ostentatious needs. In contrast to the insecure households whose expenditure is restricted to basic necessities, Moderate Prosperity households spend part of their budget on access to important services (health and education), equipment and housing, investment in activities and traditional or religious ceremonies. This finding is also supported by their ability to accede to the financial market for deposits or loans (34\% of households over the observation period of 4 years). Furthermore, the surveyed households' evaluation of their own living conditions suggests a certain awareness of their Moderate Prosperity situation. In fact, almost two-thirds of households belonging to this class recognize that given their income they cannot complain about their situation whereas half of insecure households state that life is hard.

Table 1. Characteristics of Insecure and Moderate Prosperity groups by classification variables

\begin{tabular}{lccc}
\hline & $\begin{array}{c}\text { Moderate } \\
\text { Prosperity } \\
\mathbf{N = 3 0 5}\end{array}$ & $\begin{array}{c}\text { All } \\
\text { N=508 }\end{array}$ \\
\hline Education level & $\mathbf{N = 2 0 3}$ & & \\
Illiterate & $\mathbf{9 . 9 0 \%}$ & $4.60 \%$ & $6.70 \%$ \\
Literate & $66.50 \%$ & $61.60 \%$ & $63.60 \%$ \\
Primary completed & $20.70 \%$ & $21.30 \%$ & $21.10 \%$ \\
Secondary completed and more & $3 \%$ & $\mathbf{1 2 . 5 0 \%}$ & $8.70 \%$ \\
& & & \\
Income Structure & & & \\
Rice farmers & $11.80 \%$ & $\mathbf{2 2 . 3 0 \%}$ & $18.10 \%$ \\
Agricultural workers & $\mathbf{3 0 . 0 0 \%}$ & $6.20 \%$ & $15.70 \%$ \\
Polyculture farmers & $\mathbf{2 5 . 1 0 \%}$ & $19.70 \%$ & $21.90 \%$ \\
Livestock farmers & $5.40 \%$ & $\mathbf{2 1 . 6 0 \%}$ & $15.20 \%$ \\
Independents and Non-Agricultural workers & $27.60 \%$ & $30.20 \%$ & $29.10 \%$ \\
& & & \\
Land tenure & & & \\
No title & $\mathbf{1 7 . 2 0 \%}$ & $9.20 \%$ & $12.40 \%$ \\
\hline
\end{tabular}

\footnotetext{
${ }^{11}$ The food security level is the proportion of the year without food scarcity.

12 The level of equipment was assessed by the ownership of durable goods such as bicycles, radios, TV, mobile phones, sewing machines, etc.
} 


\begin{tabular}{lccc}
\hline Traditional authorization & $41.40 \%$ & $39.70 \%$ & $40.40 \%$ \\
Locally-issued papers & $10.80 \%$ & $12.80 \%$ & $12 \%$ \\
Formal title & $30.50 \%$ & $\mathbf{3 8 . 4 0 \%}$ & $35.20 \%$ \\
\hline
\end{tabular}

Source: ROR (2008)

Notes: Bold characters mean that the value is significantly higher in the cluster than in the rest of the population (adjusted standardized residuals of chi $^{2}$ for categorical variables, $\mathrm{p}<0.05$ and independent samples t-test for continuous variables, $\mathrm{p}<0.10$ ); italic characters mean the same for values significantly lower in the cluster than in the rest of the population.

Table 2. Comparison of Household characteristics for Insecure and Moderate Prosperity groups

\begin{tabular}{|c|c|c|c|}
\hline & $\begin{array}{c}\text { Insecure } \\
\mathbf{N}=203 \\
\end{array}$ & $\begin{array}{c}\text { Moderate } \\
\text { Prosperity } \\
\text { N=305 }\end{array}$ & $\begin{array}{c}\text { All } \\
\mathrm{N}=508\end{array}$ \\
\hline \multicolumn{4}{|l|}{ Site } \\
\hline Ambohidanerana & $25.10 \%$ & $24.90 \%$ & $25 \%$ \\
\hline Anosibe Ifanja & $28.10 \%$ & $23.60 \%$ & $25.40 \%$ \\
\hline Antanetibe & $21.70 \%$ & $26.60 \%$ & $24.60 \%$ \\
\hline Merinavaratra & $25.10 \%$ & $24.90 \%$ & $25 \%$ \\
\hline \multicolumn{4}{|l|}{ HH characteristics } \\
\hline \multicolumn{4}{|l|}{ Gender } \\
\hline Male & $84.70 \%$ & $92.10 \%$ & $89.20 \%$ \\
\hline Female & $15.30 \%$ & $7.90 \%$ & $10.80 \%$ \\
\hline Age (mean) & 44 & 44 & 44 \\
\hline HH mean size & 6.75 & 5.5 & 6 \\
\hline Adults (mean) & 2.65 & 2.71 & 2.68 \\
\hline \multicolumn{4}{|l|}{ HH income and livelihoods } \\
\hline Annual income per capita (mean in PPP) & 209.13 & 600.02 & 443.819 \\
\hline Annual HH on-farm income (mean in PPP) & 658,106 & $1,639,220$ & $1,247,160$ \\
\hline Proportion of farm produce sold for income (mean) & 0.29 & 0.48 & 0.41 \\
\hline Food security level (mean) & 0,40 & 0,64 & 0,55 \\
\hline Rice production 2008 (tons) & 0.73 & 1.72 & 1.34 \\
\hline Rice yield (tons/ha) & 34.419 & 34.619 & 34.543 \\
\hline Productivity of rice land (Ar/ha)* & $1,429,320$ & $1,545,430$ & $1,500,980$ \\
\hline \multicolumn{4}{|l|}{ HH assets } \\
\hline Number of cattle (mean) & 1.78 & 3.68 & 2.92 \\
\hline Area of cultivated rice land in ha (mean) & 0.21 & 0.5 & 0.38 \\
\hline \multicolumn{4}{|l|}{ Level of equipment and durable goods } \\
\hline None & $21.70 \%$ & $5.20 \%$ & $11.80 \%$ \\
\hline Low level of equipment & $39.40 \%$ & $30.20 \%$ & $33.90 \%$ \\
\hline Minimum level of equipment & $28.10 \%$ & $24.60 \%$ & $26 \%$ \\
\hline Reasonable level of equipment & $6.90 \%$ & $20.70 \%$ & $15.20 \%$ \\
\hline Well-equipped & $3.90 \%$ & $19.30 \%$ & $13.20 \%$ \\
\hline
\end{tabular}


Based on basic necessities

Intermediate

Conspicuous consumption started

Access to Bank or micro-financial institution

No access

Access during at least part of the study period

Payment of taxes

Frequently

Never

HH's perception of own living conditions

Living well

Acceptable

Acceptable but need for vigilance

Living in difficulty

Source: ROR (2008)

Notes: Bold characters mean that the value is significantly higher in the cluster than in the rest of the population (adjusted standardized residuals of chi $^{2}$ for categorical variables, $\mathrm{p}<0.05$ and independent samples t-test for continuous variables, $\mathrm{p}<0.10$ ); italic characters mean the same for values significantly lower in the cluster than in the rest of the population.

* 1 Ariary $(\mathrm{Ar})=759$ \$ PPA in 2008.

\subsection{Second-step characterization of the Itasy Moderate Prosperity class}

This next stage of our analysis aims to specify the types of households that make up the Itasy Moderate Prosperity category. To achieve this, we conduct a mixed classification method based on three variables i.e. the household head's education level, the income structure of the household and the type of land tenure. This method consists of a hierarchical cluster analysis of the subgroups created after an initial k-means clustering of the 305 Moderate Prosperity households. After this, k-means iterations both maximize inter-group variance and minimize intra-group variance in order to provide the relevant partition i.e. the adequate number of clusters. The procedure allows us to define five clusters of Moderate Prosperity in Itasy that are strongly influenced by the agro-economic characteristics of each site. Tables 3 and 4 provide a specification for each Moderate Prosperity group based on the three active classificatory variables and other illustrative variables for characterization and comparisons.

Table 3. Characteristics of Moderate Prosperity groups by classification variables

\begin{tabular}{|c|c|c|c|c|c|c|}
\hline & $\begin{array}{c}A \\
N=108\end{array}$ & $\begin{array}{c}B \\
N=56\end{array}$ & $\begin{array}{c}C \\
\mathbf{N}=\mathbf{8 0}\end{array}$ & $\begin{array}{c}\mathrm{D} \\
\mathrm{N}=33 \\
\end{array}$ & $\begin{array}{c}E \\
N=28\end{array}$ & $\begin{array}{c}\text { All } \\
\mathrm{N}=305\end{array}$ \\
\hline \multicolumn{7}{|l|}{ Education level } \\
\hline Illiterate & $7.40 \%$ & $5.40 \%$ & $3.80 \%$ & $0 \%$ & $0 \%$ & $4.60 \%$ \\
\hline Literate & $91.70 \%$ & $76.80 \%$ & $42.50 \%$ & $0 \%$ & $42.90 \%$ & $61.60 \%$ \\
\hline Primary completed & $0.90 \%$ & $17.90 \%$ & $53.80 \%$ & $0 \%$ & $39.30 \%$ & $21.30 \%$ \\
\hline Secondary completed and more & $0 \%$ & $0 \%$ & $0 \%$ & $100 \%$ & $17.90 \%$ & $12.50 \%$ \\
\hline \multicolumn{7}{|l|}{ Income Structure } \\
\hline Rice farmers & $0 \%$ & $100 \%$ & $0 \%$ & $30.30 \%$ & $7.10 \%$ & $22.30 \%$ \\
\hline
\end{tabular}


Agricultural workers

Polyculture farmers

Livestock farmers

Independents and Non-Agricultural workers

$\begin{array}{cccccc}\mathbf{1 5 . 7 0 \%} & 0 \% & 0 \% & 0 \% & 7.10 \% & 5.90 \% \\ 0 \% & 0 \% & \mathbf{6 7 . 5 0} \% & 3 \% & 17.90 \% & 19.70 \% \\ \mathbf{4 2 . 6 0 \%} & 0 \% & 13.80 \% & 15.20 \% & 14.30 \% & 22.00 \% \\ \mathbf{4 1 . 7 0} \% & 0 \% & 18.80 \% & \mathbf{5 1 . 5 0 \%} & \mathbf{5 3 . 6 0 \%} & 30.20 \%\end{array}$

\section{Land tenure}

No title

Traditional authorization

Locally-issued papers

Formal title

\begin{tabular}{cccccc}
$0 \%$ & $0 \%$ & $0 \%$ & $0 \%$ & $\mathbf{1 0 0} \%$ & $9.20 \%$ \\
$42.60 \%$ & $44.60 \%$ & $\mathbf{5 0 \%}$ & $30.30 \%$ & $0 \%$ & $39.70 \%$ \\
$13 \%$ & $17.90 \%$ & $10 \%$ & $21.20 \%$ & $0 \%$ & $12.80 \%$ \\
$\mathbf{4 4 . 4 0 \%}$ & $37.50 \%$ & $40 \%$ & $48.50 \%$ & $0 \%$ & $38.40 \%$ \\
\hline
\end{tabular}

Source: ROR (2008)

Notes: Bold characters mean that the value is significantly higher in the cluster than in the rest of the population (adjusted standardized residuals of chi $^{2}$ for categorical variables, $\mathrm{p}<0.05$ and independent samples t-test for continuous variables, $\mathrm{p}<0.10$ ); italic characters mean the same for values significantly lower in the cluster than in the rest of the population.

Table 4. Comparison of Household characteristics between the Moderate Prosperity groups

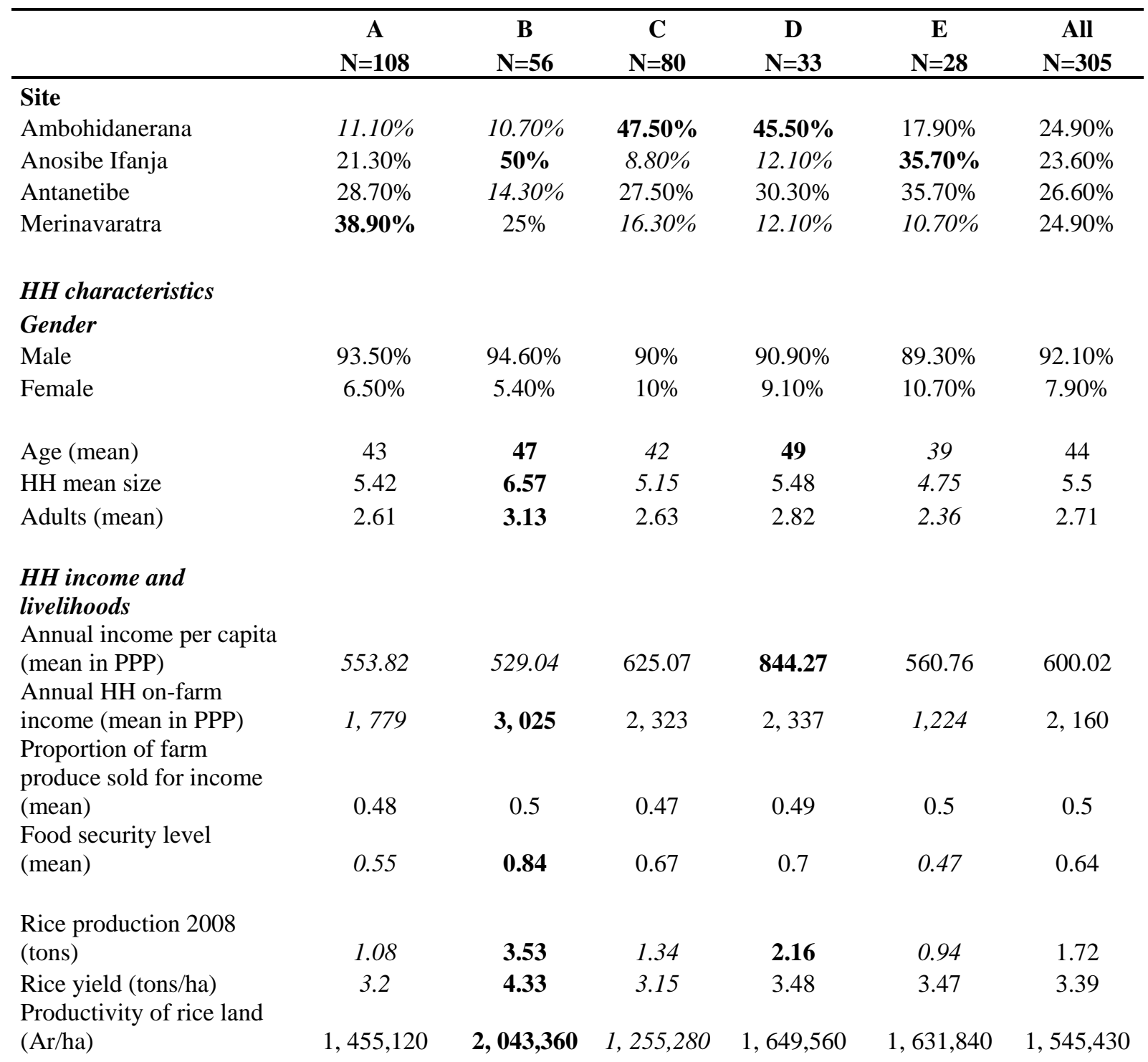


Number of cattle (mean)

Area of cultivated rice

land in ha (mean)

Level of equipment and durable goods

None

Low level of equipment

Minimum level of

equipment

Reasonable level of

equipment

Well-equipped

\section{HH behavior}

\section{Expenditure structure}

Based on basic necessities

Intermediate

Conspicuous consumption

started

Access to Bank or microfinancial institution

No access

Access during at least part of the study period

\section{Payment of taxes}

Frequently

Never

\section{HH's perception of own}

living conditions

Living well

Acceptable

Acceptable but need for

vigilance

Living in difficulty

Source: ROR (2008)

$\begin{array}{cccccc}\mathbf{4 6 . 3 0 \%} & 21.40 \% & 23.80 \% & 15.20 \% & 39.30 \% & 31.80 \% \\ 33.30 \% & 44.60 \% & 46.30 \% & 45.50 \% & 42.90 \% & 41 \% \\ & & & & & \\ 20.40 \% & 33.90 \% & 30 \% & \mathbf{3 9 . 4 0 \%} & 17.90 \% & 27.20 \%\end{array}$

$\begin{array}{cccccc}7.40 \% & 1.80 \% & 3.80 \% & 0 \% & \mathbf{1 4 . 3 0 \%} & 5.20 \% \\ \mathbf{3 7 \%} & 21.40 \% & 33.80 \% & 6.10 \% & 39.30 \% & 30.20 \% \\ & & & & & \\ 24.10 \% & \mathbf{3 5 . 7 0 \%} & 22.50 \% & 21.20 \% & 14.30 \% & 24.60 \% \\ & & & & & \\ 15.70 \% & 23.20 \% & 23.80 \% & 30.30 \% & 14.30 \% & 20.70 \% \\ 15.70 \% & 17.90 \% & 16.30 \% & \mathbf{4 2 . 4 0 \%} & 17.90 \% & 19.30 \%\end{array}$

5.13

4.27

2.5

3.68

0.33

0.88

0.53

0.59

0.22

0.5

. 
portrayed this particular characteristic of the production system of the Imerina peasantry as a strategy to cope with the failures of the rural economy. Another characteristic of the group is the prevalence of households (44\%) that hold a formal title to their rice land. This may reveal the reality of pressure on land and land fragmentation in the region and thus the necessity of securing individual tenures (Droy et al., 2010). It may also allow us to assume the potential of the households in the cluster to obtain access to formal markets such as credit, but the areas of parcels must be large enough and of sufficiently good quality. However, there are many features that highlight the vulnerability of the group. Table 4 shows that it has low mean per capita income and on-farm income, weak mean rice production and rice yield. It has also one of the poorest food security levels compared to the whole Moderate Prosperity class. This can be explained by the small size of the cultivated rice land of the households whose mean area is about 0.33 ha. $37 \%$ of households in this cluster are also poorly equipped with durable goods and $46 \%$ still base their expenditure on basic needs. However, $67 \%$ of them feel that their situation is not worthy of complaint, which suggests some awareness of their Moderate Prosperity conditions.

There is a significantly large proportion of households belonging to this category in Merinavaratra. The area is indeed characterized by poor soil and difficult access during the rainy season. Such conditions require a diversity of income sources in addition to agriculture in order to secure a livelihood. Cattle ranching, improved breeds and dairy cows are extensively found in the area, especially as farmers are interested in speculation. ${ }^{13}$ In addition, silkworm breeding and silk weaving are particularly developed in the area and can be a substantial source of income. The SAHA program provide support in promoting sericulture in the region (ROR, 2007).

\section{> Cluster B or “traditional Moderate Prosperity households"}

The second cluster is exclusively represented by rice-farming households (100\%) whose head has a rather low education level (80\% literate at best). If all households have proof of ownership of their rice land, no form of land tenure predominates, however, to characterize the group (Table 3). Looking at the other attributes, both the mean age of household heads (47 years old) and mean household size (7 members) are significantly high in the group. These features clearly suggest that the group represents the old households who have a well-established situation in rice farming which is famous in the Malagasy central highlands. The cluster may also represent the old families who have their lineage rooted in the region probably with privileged access to rice lands through inheritance. Naturally, despite the low mean per capita income of the group, the households' mean on-farm income is the highest compared to the whole Moderate Prosperity class which is due to their substantial rice production and rice yield (Table 4). This explains the good level of food security of the

\footnotetext{
${ }^{13} 56 \%$ of livestock farmers in the zone practice ranching, most pig producers are interested in improved breeds (landrace, large white) and other farmers are interested in bovine breeds (ROR, 2007).
} 
households (0.84) who manage to easily meet their food requirements for almost all of the year. The large area of their rice land $(0.88 \mathrm{ha})$ also attests to this high level of food security. In addition, the significant herd size of households in the group strengthens their comfortable endowments. They benefit from a form of insurance and particularly more oxen for farming activities. A significant proportion of households (35.7\%) have a minimum level of durable goods. These households are significantly representative of the Anosibe Ifanja zone where $45 \%$ of the cultivated land is rice paddy (ROR, 2007).

\section{$>$ Cluster C or “emerging Moderate Prosperity households”}

The third group is mostly composed of mixed farming households (68\%) whose head has a relative good level of education (54\% have completed primary school) and $50 \%$ of them have land tenure in the form of traditional authorization (Table 3). Households in the cluster are distinguished by the relatively young age of their head (40 years old) and also by their small size (Table 4). Furthermore, the cluster has low mean rice production and rice yield but a reasonable mean per capita income. This group provides a profile of young rural households who have good control over the cropping calendar and the crop rotation or intercropping practices ${ }^{14}$ that allows them to limit periods of scarcity and probably speculate in cash crops. They can be described as risk takers. The Ambohidanerana zone, where the greatest number of households in this group (48\%) are found, is well known for the presence of OFMATA that contracts with farmers and ensures input subsidies and technical support. This shows that these households devote a large part of their rice land to tobacco growing which provides them with an important source of income and cash. This substitution for rice production exposes these households to a certain degree of risk, especially as the monopoly still fixes low prices. It makes farmers dependent and may, in fact, threaten their food security because under the constraints of liquidity requirements or difficult access to markets, they are often forced to sell their production (particularly paddy rice) cheaper and buy the same food crops more expensively during periods of scarcity. In addition, Ambohidanerana is an example of the isolated rural areas where access to neighboring markets is difficult in practical terms. In fact, $28 \%$ of households admit to needing to be vigilant about their living conditions, which may reflect this situation.

\section{> Cluster D or “upper Moderate Prosperity households”}

The fourth group is wholly composed of households whose head has the highest education level (100\% finished secondary) and they are mostly in independent and nonagricultural activities (52\%). Table 4 shows that household heads in the group are the oldest in the entire Moderate Prosperity category. The cluster also features the highest mean per capita income within the whole class and a significant mean rice production despite their non-

\footnotetext{
${ }^{14}$ Maize-bean intercropping and crop rotations alternating root crops (cassava) and seed plants (rice) are often practised in Itasy (ROR, 2007).
} 
agriculturally-oriented income structure. Households in this group are particularly distinguished by their high level of equipment. They are also relatively well endowed with rice land, with a mean surface of 0.6 ha. This well-off cluster of independents and nonagricultural workers is the only one with a significant proportion of households whose basic necessities are no longer a top concern. They begin to clearly orient their spending towards conspicuous consumption and status. With a large proportion of public employees, this group consists mainly of the few schoolteachers and some administrative employees in the study areas. The rare households having the most profitable independent activities may also have been captured in this cluster. The over-representation of the latter in the Ambohidanerana zone is probably due to the scarcity of other agriculture-based profiles in that zone.

\section{> Cluster E or “low Moderate Prosperity households"}

The last, and smallest, group is represented by households who are almost specialized in independent and non-agricultural activities (54\%) and whose head has a relatively good education level (39\% have completed primary school). The cluster is particularly distinguished by the absence of any proof of land ownership for any of the households (Table 3). The group includes the youngest households within the Moderate Prosperity category with the lowest mean age of household head (39 years) and the smallest mean household size (Table 4). The cluster finds it difficult to meet its food requirements with the lowest food security level (0.47). This can be explained by its very poor mean rice production, despite fairly good mean rice yield and mean rice productivity. The very small area of rice land of households in the group (only 0.22 ha) undoubtedly explains this finding, even more so given that rice farmers are under-represented. The low endowments of the households are also characteristic of the group, with a low mean number of cattle and a low level of equipment in durable goods. Moreover, this cluster of non-agricultural smallholders is to a certain extent outside the system because $61 \%$ of its households never pay land taxes. This relates to their absence of land tenure or simply the lack of available rice land for some of them. This category describes the profile of young households who are just beginning to earn their livelihoods and so in their early accumulation phase. They are particularly constrained by the lack of access to rice land. Hence, they are obliged to derive most of their income from nonagricultural activities, such as non-food crafts. This makes such households vulnerable and risk averse because they might lose everything in the event of a negative shock. There is a significantly large proportion of households belonging to this category in Anosibe Ifanja, a zone where independent activities are little developed in comparison to the high level of rice production. The presence of LECOFRUIT may allow some of these smallholders to contract with the company to produce green beans.

The predominance of household profiles turned towards non-farm activities, among the five clusters, suggests that they have adopted relatively successful strategies to overcome land and population pressures. This may also imply that the process of structural change in Malagasy rural areas could operate through these diversified Moderate Prosperity households. 
In any case, the conditions of some of them, especially due to structural failures in the rural economy, reveal the fragility of this process.

The five Moderate Prosperity clusters identified in Itasy can in fact be divided into three main groups in terms of vulnerability to shocks. The most vulnerable are clusters A and E. Households in these categories, particularly in E, have a high risk of experiencing a drop in their income and well-being in the case of negative shocks. Households in cluster $\mathrm{C}$ form an intermediary group whose livelihoods are relatively secure thanks to their having good control over crop diversity. Clusters B and D form a group with a good degree of stability. They are probably resistant to possible negative shocks thanks to their high level of land endowments and/or education.

\section{Conclusion}

This paper reports our work on testing the adaptation of the Middle Class concept to African agriculture-based countries by focusing on rural areas using the case of the Moderate Prosperity category in the Itasy region of Madagascar. There is uncertainty about the positive effects of the emergence of a GMC on socioeconomic development and political stability. However, a re-appropriation of this controversial sociological concept in development economic literature is an interesting framework for understanding ongoing socioeconomic changes in developing countries. It allows us to shed light on a category of non-poor people who are often ignored by the literature and to emphasize the development potential of these countries. In African agriculture-based countries, focus on the rural areas appears to be essential given the importance of agriculture and the rural sector in their economy. Despite the limited stratificationist approach of the concept, the application of the two-step identification process used by Bonnefond et al. (2015), enabled us to give a multidimensional aspect to the definition of this category. We then refined the income-based identification of the Itasy Moderate Prosperity households by considering the education level of the household head, their income structure and the form of their rice land tenure. This adaptation of the Middle Class concept to rural areas is based on Darbon and Toulabor (2011)'s proposal that one should focus on people who may still be vulnerable but live in limited prosperity. We have bypassed the general patterns and high-level criteria used by most existing studies by adopting a case study in the Itasy rural area.

We first identified the Middle Class category of households taking those who are in the top three quintiles of the annual gross income per capita. Besides having removed the most insecure from the analysis, we found significant differences between the two groups in terms of household characteristics, livelihood, asset ownership, and socioeconomic behavior and even in their own evaluation of their living conditions. We then conducted a multidimensional classification of the Moderate Prosperity households thus identified, taking the three variables that are considered to be important in the Itasy context simultaneously. Five heterogeneous groups have been described and they reflect the particular agro-economic characteristics of the different zones in Itasy: (i) the large, vulnerable, Moderate Prosperity cluster of nonagricultural and livestock farmers with formal land title but with uneducated household heads, 
(ii) the traditional Moderate Prosperity cluster of uneducated rice farmers with large holdings, (iii) the emerging Moderate Prosperity cluster of polyculture farmers with a higher education level and traditional land ownership, (iv) the upper Moderate Prosperity group of skilled nonagricultural workers composed mostly of schoolmasters and administrative employees and (v) the low Moderate Prosperity cluster of smallholders in independent and non-farm activities with a higher education level but without any secure land tenure.

Most of these Moderate Prosperity groups reflect the dynamics of rural households in Itasy through the adoption of developing strategies in a hostile rural context. The diversified strategies of some of them may suggest that they could be drivers of structural change on a local scale. However, they are subject to both exogenous and endogenous structural deficiencies that still make them vulnerable to negative shocks or socioeconomic downturns. The trajectories and the long term security of the livelihood of these Moderate Prosperity households still depend on the actions of the government in respect of rural development. 


\section{References}

Acemoglu, D., Zilibotti, F. 1997, “Was Prometheus Unbound by Chance?”, Journal of Political Economy, 105(4): 709-51.

African Development Bank (AfDB), 2001, “Africa in 50 Years’ Time: The Road Towards Inclusive Growth”. Tunis: AfDB.

Andrianirina, N., Benoit-Cattin, M., David-Benz, H. 2010, "Diversité, diversification et inégalités chez les ménages ruraux. Le cas de l'observatoire rural de Fénérive Est à Madagascar”, Communication 4èmes Journées de recherches en sciences sociales, AgroCampus-Ouest, Rennes.

Ballet, J. and Randrianalijaona, M. 2010, « Quand les inégalités régulent la pression sur les ressources forestières : Une comparaison entre deux sites dans la région SAV, Nord-Est de Madagascar ", Working papers 42010, Fonds pour la Recherche en Ethique Economique.

Banerjee, A., Duflo, E. 2008, “What is middle class about the middle classes around the world?”, Journal of Economic Perspectives, 22(2): 3-28.

Bezemer, D., Headey, D. 2008, "Agriculture, Development, and Urban Bias", World Development, Elsevier, 36(8): 1342-1364, August.

Bidou-Zachariasen, C. 2004, “Les classes moyennes: definitions, travaux et controverses”, Education et sociétés, $\mathrm{n}^{\circ} 14$, p. 119-134.

Birdsall, N., Graham, C., Pettinato, S. 2000, "Stuckt in the tunnel: is globalization muddling the Middle Class”, Center on Social and Economic Dynamics, Working paper n 4.

Birdsall, N. 2007, "Do No Harm: Aid, Weak Institutions, and the Missing Middle in Africa”, Center for Global Development, Working Paper $\mathrm{n}^{\circ} 117$.

2010, "Reflections on the Macro Foundations of the Middle Class in the Developing World”, Center for Global Development, Working Paper n¹30.

Bockel, L. 2005, Politiques publiques et pauvreté à Madagascar. La filière riz, moteur de croissance ou facteur de crise ?, Paris : L’Harmattan.

Bonnefond, C., Clément, M., Combarnous, F. 2015, 'In search of the elusive Chinese urban middle class: An exploratory analysis’, Post-Communist Economies, 27 (1).

Bosc, S. 2008, Sociologie des classes moyennes. Repères. Ed La découverte, Paris.

Castellani, F., Parent, G. 2011, 'Being 'middle class’ in Latin America', OECD Development, Centre Working Paper n³05.

Chun, N., Hasan, R., Ulubasoglu, M. 2011, “The role of the middle class in economic development: What do cross-country data show?”, ADB Economics Working Paper, n²45.

Darbon,D., Toulabor, C. 2011, «Quelle(s) classe(s) moyenne(s) en Afrique? Une revue de littérature», Agence Française de Développement, Working paper nº118. 
Darbon, D. 2012, « Classes(s) moyenne(s): une revue de la literature. Un concept utile pour suivre les dynamiques de l'Afrique », Afrique contemporaine, 4 (244) : 33-51.

Dercon S. 2005, Insurance Against Poverty, Oxford, New York, Oxford University Press.

Diao, X., Hazell, P., Resnick D., Thurlow J. 2006, "The Role of Agriculture in Development: Implications for Sub-Saharan Africa”, International Food Policy Research Institute, Development Strategy and Governance Division, Paper No 29.

Doepke, M., Zilibotti, F. 2005. "Social class and the Spirit of Capitalism”. Journal of the European Economic Association, 3(2-3) : 516-24.

Droy, I., Dubois, J-L. 2001, «L'observatoire: un instrument pour le suivi de la pauvreté », Working paper CED DT/59/2001, Université Montesquieu-Bordeaux IV. (http://www.montesquieu.ubordeaux.fr/ced).

Droy, I., Bidou, J-E., Rasolofo, P., 2010, « Pauvreté et sécurisation foncière : les atouts et incertudes d'une gestion décentralisée à Madagascar 1 », TALOHA, n¹9, http://www.taloha.info/document.php?id=867.

Easterly, W. 2001, “The Middle Class Consensus and Economic Development”, Journal of Economic Growth, Vol. 6, pp. 317-335.

Ferreira, F. H. G., Messina, J., Rigolini, J., López-Calva, L.F., Lugo, M. A., Vakis, R. 2013."Economic Mobility and the Rise of the Latin American Middle Class”. Washington, DC: World Bank. doi: 10.1596/978-0-8213-9634-6.

Gondard-Delcroix, C . 2006, «Diversification des activités et dynamiques de pauvreté en milieu rural malgache. Entre gestion des risques et barrières à l'entrée ", Septièmes journées du réseau Analyse Economique et Développement de l'Agence Universitaire de la Francophonie (AUF) (7-8) Septembre 2006, France.

Grootaert, C., Kanbur, R., Oh, G-T.1995, “The Dynamics of Poverty. Why Some People Escape from Poverty and Others Don't. African Case Study”, World Bank, Policy Research Working Paper 1499.

Kharas, H. 2010, 'The emerging middle class in developing countries », OECD Development Center Working Paper, $\mathrm{N}^{\circ} 285$.

King, L.P. and Szelenyi, I. 2004, Theories Of The New Class: Intellectuals And Power (Contradictions of Modernity), University of Minnesota Press.

Leonard, M. 2008, China 3.0, European Council On foreign relations, United Kingdom.

Lewis, A. 1954, "Economic development with unlimited supplies of labor", Manchester School of economic and social studies, n²2, pp. 139-191.

Loayaza, N.V., Rigolini, J. 2012, “Do Middle Classes Bring Institutional Reforms”, Institute for the Study of Labor (IZA), IZA Discussion Papers 6430.

Lopez-Calva, L.F., Ortiz-Juarez, E. 2011, "A vulnerability Approach to the Definition of the Middle Class”, Policy Research Working Paper, 5902. 
Lopez-Calva, L.F. Torche F. 2011, "Stability and vulnerability of the Latin American middle class", Dilemnas of the Middle Class around the World.

Losch B., Fréguin - Gresh S., White E. 2011, 'Rural Transformation and Late Developing Countries in a Globalizing World. A Comparative Analysis of Rural Change'. Final Report of the RuralStruc Program, Revised Version. Washington, DC: World Bank.

Milanovic, B., Yitzhaki, S. 2002, "Decomposing the world income distribution: Does the world have a middle class?”, Review of Income and Wealth, 48(2): 155-178.

Ncube, M., Shimeles, A. 2012, "The making of the middle class in Africa”, African Development Bank.

Prahalad, C.K. 2010, The fortune at the Bottom of the Pyramid. Eradicating Poverty through profits, Prentice Hall, New York.

Pressman, S. 2007, "The decline of the middle class: An international perspective", Journal of Economic Issues, 38(4):445-454.

Rabearimanana, G. 1994, «Le Boina », in Raison J-P., Paysanneries malgaches dans la crise, Ed. Karthala, Paris.

Randrianarison, L., Andrianirina, N., Ramboarison, R. 2007, «Dimensions structurelles de la libéralisation pour l'agriculture et le développement rural », Programme RuralStruc-Phase I

2009, «Dimensions structurelles de la libéralisation pour l’agriculture et le développement rural », Programme RuralStruc-Phase II

Rakoto-Ramiarantsoa, H. 1994, «L’Imerina », in Raison J-P., Paysanneries malgaches dans la crise, Ed. Karthala, Paris.

Rakotovao , J-M., Bockel, L. 2001, « Stratégies de sortie de la pauvreté chez les ménages ruraux et politiques de reduction de la pauvreté », Note de travail UPDR.

Ravallion, M. 2010, “The Developing World's Bulging (but Vulnerable) Middle Class”, World Development, 38(4): 445-454.

Razafimandimby, L. 1998, «L'ajustement structurel dans le secteur agricole de Madagascar : insuffisance des réformes de prix et faiblesse de la compétitivité », Centre d'économie du développement, Université Montesquieu-Bordeaux IV.

Roubaud, F. 1996, "La Question Rizicole à Madagascar: les résultats d’une décennie de liberalization”, Projet Madagaqcar-Dial-Instat-Orstom n9640/E.

Réseau des Observatoires Ruraux 2007, « Rapport d'enquête communautaire de l'Observatoire Rural d'Itasy », Campagne 2007.

Senauer, B., Goetz, L. 2003, “The growing middle class in developing countries and the market for high-value food products”, The food Industry Center, University of Minnesota.

Stavenhagen R. 1969, Les classes sociales dans les sociétés agraires, Editions Anthropos, Paris. 
Torche, F., Lopez-Calva, L. 2011, "Stability and Vulnerability of the Latin American Middle Class". In Newman, K (ed), Dilemmas of the Middle Class around the World, Oxford University Press.

Xianchun, X. 2009, “The system of xiaokang indicators: a framework to measure China's progress”. OECD World Forum, Busan, Korea.

Wampfler, B., 2007, "Les besoins de financement de "nouveaux" acteurs économiques, les entrepreneurs ruraux”, BIM nº-9 octobre 2007.

World Bank 2007, “Global Economic Prospects 2007: Managing the New Wave of Globalization”, The World Bank, Washington D.C.

World Bank Report 2008, “Agriculture for development”, The World Bank, Washington D.C. 


\title{
Cahiers du GREThA Working papers of GREThA
}

\author{
GREThA UMR CNRS 5113 \\ Université de Bordeaux \\ Avenue Léon Duguit \\ 33608 PESSAC - FRANCE \\ Tel : +33 (0)5.56.84.25.75 \\ Fax : +33 (0)5.56.84.86.47 \\ http://gretha.u-bordeaux4.fr/
}

\section{Cahiers du GREThA (derniers numéros - last issues)}

2014-09 : FRIGANT Vincent, ZUMPE Martin, Are automotive Global Production Networks becoming more global? Comparison of regional and global integration processes based on auto parts trade data

2014-10: BEN OTHMEN Asma, De la mise à contribution des bénéficiaires au financement de la préservation des espaces naturels : tarification de l'accès ou augmentation de taxe?

2014-11: MENON Carlo, Spreading Big Ideas? The effect of Top Inventing Companies on Local Inventors

2014-12 : MIGUELEZ Ernest, Inventor diasporas and the internationalization of technology

2014-13 : CARAYOL Nicolas, CASSI Lorenzo, ROUX Pascale, Unintended triadic closure in social networks: The strategic formation of research collaborations between French inventors

2014-14 : CARAYOL Nicolas, LAHATTE Agenor, Dominance relations and ranking when quantity and quality both matter: Applications to US universities and econ. departments worldwide

2014-15: BIANCHINI Stefano, LISSONI Francesco, PEZZONI Michele, ZIRULIA Lorenzo, The economics of research, consulting, and teaching quality: Theory and evidence from a technical university

2014-16 : LISSONI Francesco, MIGUELEZ Ernest, Patents, Innovation and Economic Geography

2014-17 : BHUKUTH Augendra, BALLET Jérôme, RABEVOHITRA Bako Nirina, RASOLOFO Patrick, Analysing the effects of crops shocks on child work : the case of the Marondava district in Madagascar

2014-18 : Alexandre BERTHE, LUC ELIE, Les conséquences environnementales des inégalités économiques : structuration théorique et perspectives de recherche

2014-19 : Alexandre BERTHE, Sylvie FERRARI, Justice écologique et adaptation au changement climatique : le cas des petits territoires insulaires

2014-20: ANDRIANAMPIARIVO Tsiry, Moderate Prosperity, an adaptation of the Middle Class concept to a Malagasy rural area: the case of Itasy

La coordination scientifique des Cahiers du GREThA est assurée par Emmanuel PETIT. La mise en page est assurée par Anne-Laure MERLETTE. 